\title{
Cervical Myelopathy Due to Chronic Overshunting in a Pediatric Patient: Case Report and Review of the Literature
}

\section{Pediatrik Bir Hastada Kronik Fazla Şant Nedeniyle Servikal Miyelopati: Olgu Sunumu ve Literatürün Gözden Geçirilmesi}

Nils Harry-Bert ULRICH ${ }^{1}$, Matthias MAIER ${ }^{2}$, Rene-Ludwig BERNAYS ${ }^{1}$, Niklaus KRAYENBUHL ${ }^{1}$, Spyros KOLLIAS ${ }^{2}$

${ }_{1}$ University Hospital of Zurich, Department of Neurosurgery, Zurich, Switzerland

${ }^{2}$ University Hospital of Zurich, Department of Neuroradiology, Zurich, Switzerland

Corresponding Author: Nils Harry-Bert ULRICH / E-mail: nils.ulrich@usz.ch

\begin{abstract}
We present a rare cause of cervical myelopathy produced by an engorged suboccipital epidural venous plexus due to chronic cerebrospinal fluid (CSF) overdrainage. A 17-year-old boy with obstructive hydrocephalus due to a retrocerebellar cyst and secondary implantation of a ventricloperitoneal shunt (VP-shunt) presented with progressive spastic tetraparesis. MRI imaging revealed myelopathy due to significant compression of the cervical spinal cord by engorged epidural veins. Further assessment at a low-pressure setting revealed a broken shunt valve. The VP-shunt valve was changed with an additional anti-siphon device leading to a gradual increase of the intracranial pressure (ICP). After intensive physiotherapy, the patient showed slight clinical improvement. Follow-up imaging within nine days showed distinct regression of the dilated venous plexus at the cranial-cervical junction (CCJ) with the resolution of cord compression. Engorgement of the epidural venous plexus should always be considered in the differential diagnosis of myelopathy in long-term shunt patients even when classical clinical and radiological signs of overshunting are missing.
\end{abstract}

KEYWORDS: Cervical myelopathy, Ventriculoperitoneal shunt complication, Intracranial hypotension, Epidural venous plexus

öz

Kronik serebrospinal sıvı aşırı drenajı nedeniyle genişlemiş bir suboksipital epidural venöz pleksusun neden olduğu nadir bir servikal miyelopati durumu bildiriyoruz. Retroserebellar kist nedeniyle obstrüktif hidrosefalisi olan ve bir ventiküloperitoneal şantın (VP şant) sekonder olarak implante edilmiş olduğu 17 yaşında bir erkek progresif spastik tetraparezi ile geldi. MRG genişlemiş epidural venler nedeniyle servikal omurilikte önemli ölçüde kompresyona bağlı miyelopati gösterdi. Düşük basınç ayarında daha ileri değerlendirme kırılmış bir şant valfi ortaya çıkardı. VP şant valfi ek bir antisifon cihazla birlikte değiştirildi ve intrakraniyal basınçta giderek artış oldu. Yoğun fizyoterapi sonrasında hastada hafif klinik düzelme görüldü. Dokuz gün sonrasındaki takip görüntüleme kraniyal ve servikal bileşkedeki dilate venöz pleksusta belirgin küçülme ve omurilik kompresyonunun geçmesini gösterdi. Epidural venöz pleksusun genişlemesi klasik kronik ve radyolojik fazla şant bulguları bulunmasa bile uzun dönemli şant hastalarında miyelopati ayırıcı tanısında daima dikkate alınmalıdır.

ANAHTAR SÖZCÜKLER: Servikal miyelopati, Ventriküloperitoneal şant komplikasyonu, İntrakraniyal hipotansiyon, Epidural venöz pleksus

\section{INTRODUCTION}

Chronic cerebrospinal fluid (CSF) overdrainage typically manifests with orthostatic headache, nausea, vomiting and neck pain (10). In this situation, enhancing meninges and downward displacement of the tonsils are the most frequently reported radiological findings $(1,12)$. Compressive myelopathy as a result of an engorged epidural venous plexus, primarily due to intracranial hypotension, without associated typical signs of overdrainage led to the initial misdiagnosis. We report our primary findings and pitfalls before the primary etiology was revealed.

\section{CASE REPORT}

\section{History and Examination}

A 17-year-old boy presented with progressive paraparesis in his legs. At the age of one and a half, he was diagnosed with obstructive hydrocephalus due to a retrocerebellar arachnoidal cyst on the right side, for which he underwent ventricular and cysto-peritoneal shunting. Three years after initial placement, the shunt was replaced by a " $\mathrm{Y}$ " connector. Six years later, a complete shunt revision was necessary due to shunt failure. The shunt was equipped with a programmable valve. The patient started walking late at the age of five but attended elementary school without any difficulties. Since 
then, he had no problems walking and his medical course was unremarkable.

At the age of fifteen, he slowly developed gait disturbances with stiffness in both legs. Clinical examination showed slightly elevated muscle tone in the upper extremities with prolonged reflex zones. Increased muscle tone at the lower extremities with positive Babinski sign bilaterally and a spastic gait were observed. MR imaging of the cervical spine showed a greatly dilated suboccipital venous plexus with compression of the spinal cord. An arteriovenous malformation (AVM) was excluded by selective digital subtraction angiography (DSA), showing only dilated veins without fistulas. No signs of myelopathy were seen at that point. Three months later, the boy showed rapid progression of his gait problems. Repeated MRI of the cervical spine demonstrated progressive spinal cord compression with newly developed signal alterations suggestive of myelopathy on levels C2 to C3 (Figure 2A-D). A neoplastic process was initially discussed in the differential diagnoses but was excluded by the neuroradiologists, and biopsy was avoided. The suspicion of extramedullary hematopoesis in the cervical spine was also discussed due to associated immense thickening of the skull, as seen on the initial MRI (Figure 1A, B). The suspicion of thalassemia was assumed but could not be confirmed. At that point, if the condition worsens, decompression of the posterior cervical spine is the primary recommendation for therapy. Based on the MRI and MR-angiography showing that the epidural mass apparently consisted of dilated epidural veins (Figure $3 \mathrm{~A}, \mathrm{~B})$, the diagnosis of cervical myelopathy due to chronic overshunting was suggested by the neuroradiologists.

\section{Preoperative Assessment, Surgery and Discharge}

The last documented shunt valve setting was low at $7 \mathrm{cmH} 20$. In order to assess whether the young patient was dependant on his shunt or whether his symptoms were caused by shunt overdrainage, we decided to gradually increase valve pressure. This was tried three times without any success, assuming malfunction of the shunt valve. To change the shunt valve and to assess shunt flow dynamics, surgery was planned for the next day. Intra-operatively, the abdominal shunt drainage was tested successfully. There was abdominal flow without any resistance. The new programmable valve with an anti-siphon guard was connected and set at $9 \mathrm{cmH} 20$. Forty-eight hours after the operation, the patient was fully mobile. During the rest of his stay, the new programmable shunt valve was continuously changed to higher pressures. The final setting was $13 \mathrm{cmH} 20$. The new setting was tolerated without any sign of hydrocephalus. Nine days after the operation, we performed another MRI of the brain and cervical spine, which showed an impressive reduction in the size of the epidural veins with the disappearance of cord compression. Some slight deformation of the cord remained, and myelopathy was still seen at levels C2 to C3 (Figure 2AD). At discharge, the patient described a slight improvement in his legs with less spasticity and reduced weakness, which was also documented clinically. An intensive rehabilitation program was initiated, unfortunately with only slight further improvement.

\section{DISCUSSION}

Cervical compression with myelopathy due to engorged
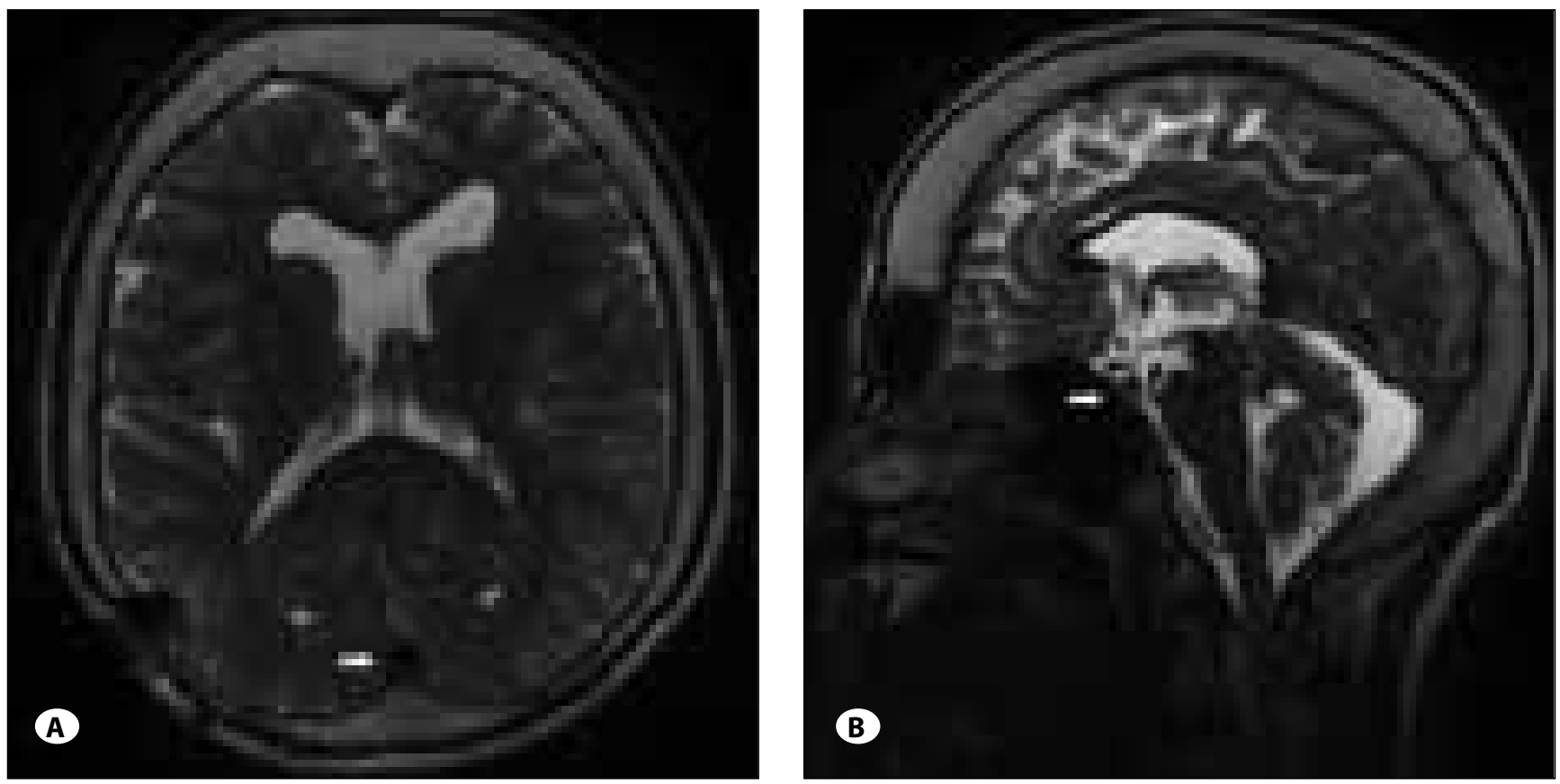

Figure 1: An axial T2-weighted MR-image (A) shows the insert tip of the VP-shunt in the right lateral ventricle. Note that the ventricles are not dilated. The rounded superior sagittal sinus (white arrow) (B) and the midsagittal T2-weighted MR-image demonstrates severe bone thickening of the calvarium and prominence of the hypophyseal gland (white arrow). Note the lack of any caudal displacement of the cerebellum. 


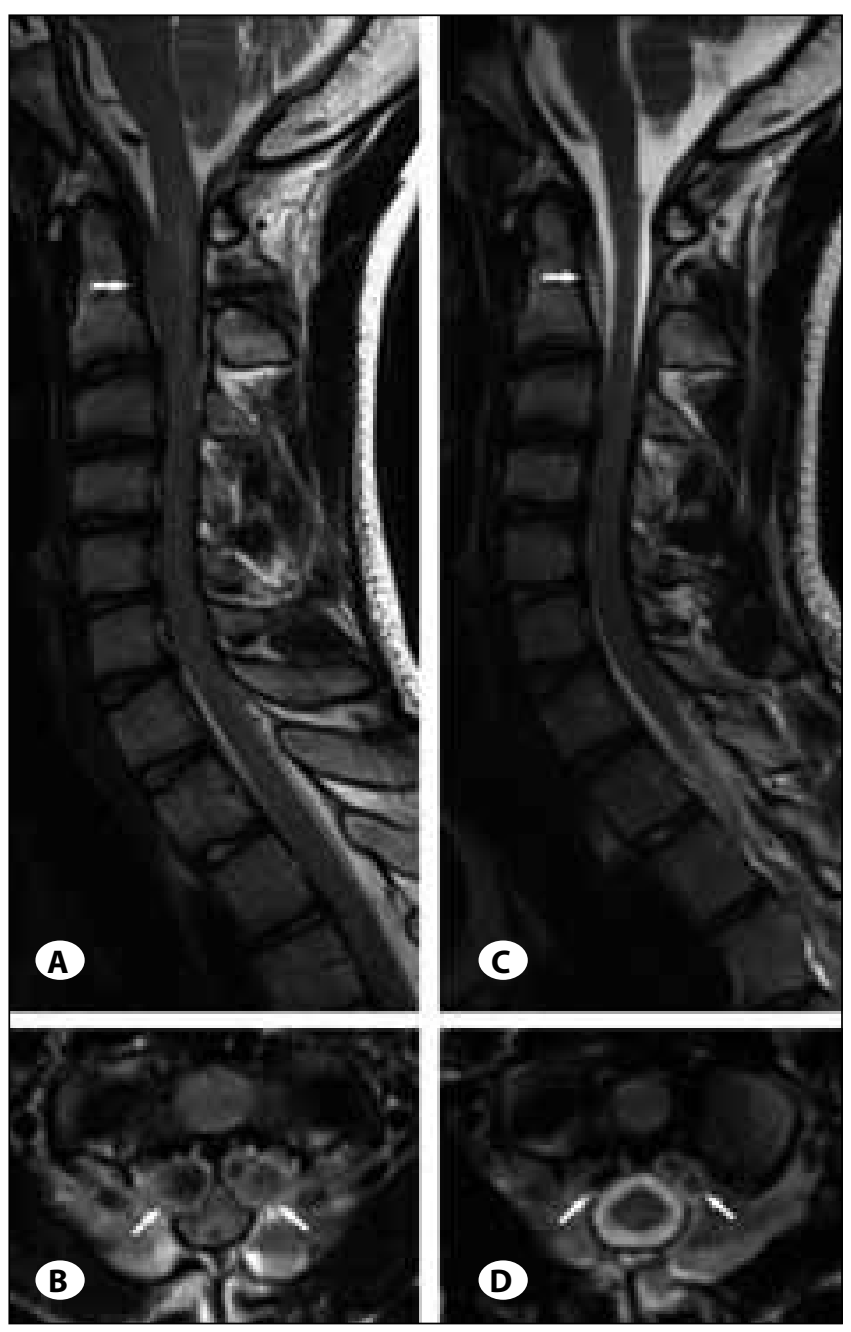

Figure 2: Sagittal (A, C) and axial (B, D) T2-weighted MR-images obtained before (A, B) and 9 days after shunt revision (C, D). A massive, enlarged anterior epidural venous plexus is depicted before the operation ( $a, b$; white arrows). Nine days after the operation (C, D), vein engorgement is clearly reduced (white arrows). The resolution of cord compression is obvious. The slight persistence of cord deformation and signs of myelopathy from chronic cord compression are still present.

epidural veins from CSF overdrainage is a rare shunt complication and should always be considered in the differential diagnosis of myelopathy in shunt-dependent patients. Hydrodynamic changes can affect the complex venous anatomy of the craniocervical junction (CCJ), leading to engorgement of the epidural venous plexus and secondary cord compression.

\section{Case Evaluation}

Our presented case illustrates a rare complication of myelopathy caused by chronic shunt overdrainage. This case facilitates several conclusions. Firstly, the classical symptoms in CSF overdrainage such as postural headache, nausea, vomiting, neck pain, diplopia or vertigo $(3,13)$ may be absent, thus misleading the initial diagnosis. Secondly,

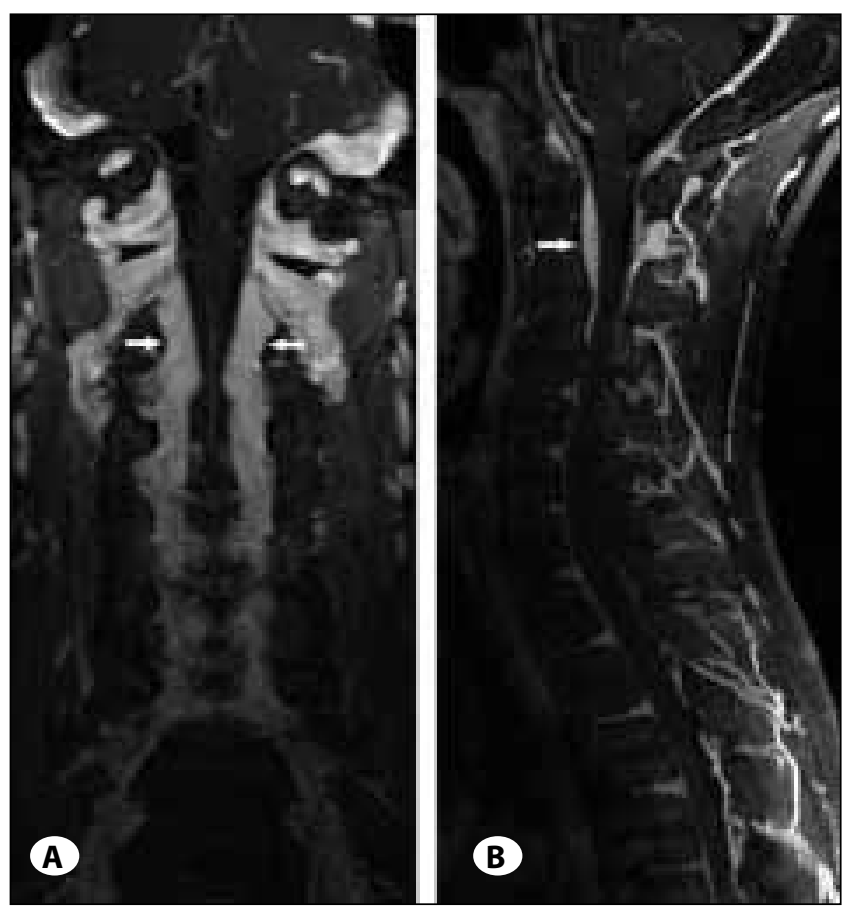

Figure 3: The venous phase of contrast-enhanced MRangiography in the (A) coronal and $(\mathbf{B})$ sagittal plane shows the engorged epidural veins on C2-C3 (white arrows).

lack of awareness of this rare entity may lead to a significant delay in diagnosis and, therefore, a delay in the provision of appropriate treatment.

Furthermore, classical radiological signs of intracranial hypotension and overdrainage likeslitventricles, rostral-caudal brain displacement $(1,12)$ may also be absent. This might also explain why the patient had no headaches as expected. In MR imaging the appearances of round shaped venous sinuses, cranial convexity of the pituitary and hyperostosis of the skull were seen (Figure 1A, B). Skull hyperostosis further misled the initial diagnosis, leading to the assumption that a generalized, hematopoietic or metabolic process represented the more likely diagnosis. A review of the literature revealed a previous case of chronic ventricular shunting associated with calvarial thickening (5). Additionally, the lack of awareness of this entity may lead to other temporal treatment options, such as surgical decompression of the cervical spine or performance of diagnostic biopsy for the epidural compressing "mass," which is associated with a potentially harmful outcome for the patient. Fortunately, both were avoided in our case due to timely diagnosis based on neuroradiology.

An extensive review of the literature revealed a few similar cases $(2,4,6-8,14,15)$ (Table I). None of them presented with classical symptoms of CSF overdrainage, but in the case of Wolfe et al., a diffuse dural enhancement was seen, suggesting the diagnosis of cerebral hypotension. In comparison to ours, only slight dural enhancement was seen. In 1998, Miyazaki and coworkers (8) described a case in which a patient who was 


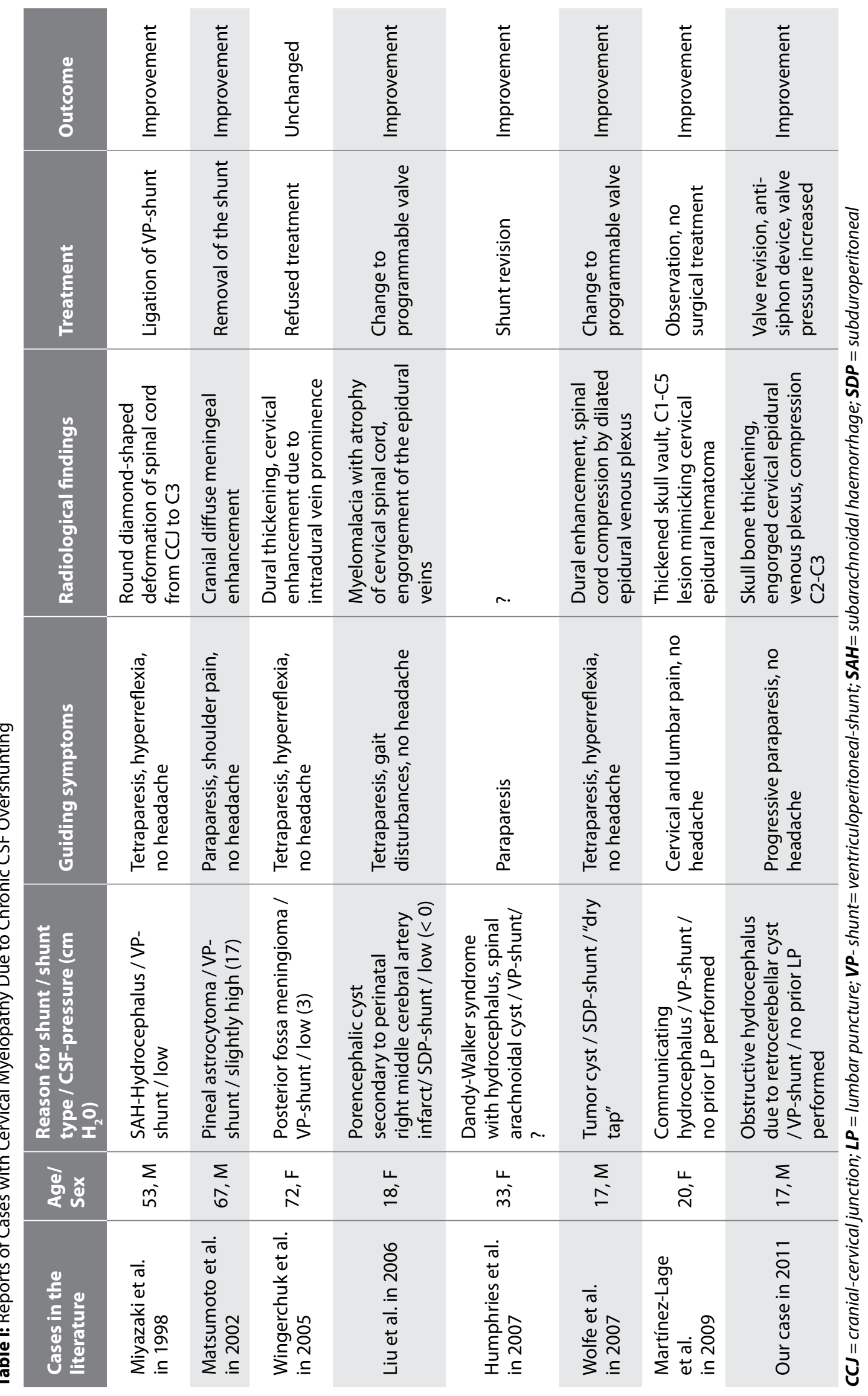


VP-shunted with a low-pressure valve due to subarachnoidal hemorrhage developed mild myelopathy. MR imaging revealed dilated epidural veins in the craniocervical junction with deformation of the spinal cord. Miyazaki et al. performed shunt ligation with almost complete clinical improvement. In summary, awareness of the rare complication in patients who are shunted over the long-term should always be considered for timely diagnosis and improved clinical outcomes. In our case faster treatment could have prevented progressive myelopathy and allowed for improved clinical outcome.

\section{Pathophysiology}

In a recent paper (15) by Wolfe et al., the underlying pathophysiological mechanisms leading to the engorgement of the epidural veins were described and very well illustrated. The pathophysiology must be understood in the context of the Monro-Kellie doctrine (9). Monro and Kellie declared that the sum of intracranial blood and tissue volume remains constant. As long as the craniospinal system is intact, levels of all fluids such as blood and CSF are expected to remain stable. A deficit in one component will result in an excess of the others. In our case, the depletion of CSF resulted in engorgement of the epidural venous plexus. When venous engorgement becomes chronic, Mokri et al. (11) reported that fibrocollagenous proliferation contributes to dural thickening; this secondary factor could explain the spinal cord compression observed. Our patient had congenital mild cervical spinal stenosis; this might have aggravated the spinal compression due to cervical engorgement of the veins.

\section{CONCLUSION}

Chronic cerebrospinal fluid overdrainage can lead to the rare but devastating problem of cervical myelopathy due to spinal cord compression by the dilated epidural venous plexus. The knowledge of this differential diagnosis can prevent an unnecessary delay in treatment and therefore improve outcome significantly.

\section{CONFLICTS of INTEREST}

None

\section{REFERENCES}

1. Comabella A, Grive M, Rovira Isern E, Montalban Gaerin $X$ : Postcontrast dural MR enhancement and acute CSF intracranial hypotension. J Comput Assist Tomogr 19: 1008-1009, 1995

2. Humphries WE, Grossi PM, Liethe LG, George TM: Ventriculoperitoneal shunt failure causing myelopathy in a patient with bilateral jugular vein occlusion. Case report. J Neurosurg Spine 6:60-63, 2007
3. Jacobs $M B$, Wasserstein $\mathrm{PH}$ : Spontaneous intracranial hypotension. An uncommon and underrecognized cause of headache. West J Med 155:178-180, 1991

4. Liu JK, Gottfried ON, Brockmeyer DL: Epidural venous engorgement resulting in progressive cervical myelopathy from shunt-related intracranial hypotension. Case report and review of the literature. J Neurosurg 105:499-503, 2006

5. Lucey BP, March GP, Jr, Hutchins GM: Marked calvarial thickening and dural changes following chronic ventricular shunting for shaken baby syndrome. Arch Pathol Lab Med 127:94-97, 2003

6. Martinez-Lage JF, Ruiz-Espejo AM, Almagro MJ, Alfaro R, Felipe-Murcia M, Lopez-Guerrero AL: CSF overdrainage in shunted intracranial arachnoid cysts: A series and review. Childs Nerv Syst 25:1061-1069, 2009

7. Matsumoto K, Ohta M, Takeshita I: Symptomatic spinal extramedullary mass lesion secondary to chronic overdrainage of ventricular fluid--case report. Neurol Med Chir (Tokyo) 42:140-142, 2002

8. Miyazaki T, Chiba A, Nishina H, Uesaka Y, Nakase H, Kanazawa I: Upper cervical myelopathy associated with low CSF pressure: A complication of ventriculoperitoneal shunt. Neurology 50:1864-1866, 1998

9. Mokri B: The Monro-Kellie hypothesis: Applications in CSF volume depletion. Neurology 56:1746-1748, 2001

10. Mokri B: Headaches caused by decreased intracranial pressure: Diagnosis and management. Curr Opin Neurol 16:319-326, 2003

11. Mokri B, Parisi JE, Scheithauer BW, Piepgras DG, Miller GM: Meningeal biopsy in intracranial hypotension: Meningeal enhancement on MRI. Neurology 45:1801-1807, 1995

12. Pannullo SC, Reich JB, Krol G, Deck MD, Posner JB: MRI changes in intracranial hypotension. Neurology 43:919-926, 1993

13. Teng $P$, Papatheodorou C: Primary cerebrospinal fluid hypotension. Bull Los Angeles Neurol Soc 33:121-128, 1968

14. Wingerchuk DM, Patel NP, Patel AC, Dodick DW, Nelson KD: Progressive cervical myelopathy secondary to chronic ventriculoperitoneal CSF overshunting. Neurology 65: 171-172, 2005

15. Wolfe SQ, Bhatia S, Green B, Ragheb J: Engorged epidural venous plexus and cervical myelopathy due to cerebrospinal fluid overdrainage: A rare complication of ventricular shunts. Case report. J Neurosurg 106:227-231, 2007 